PERM JOURNAL OF PETROLEUM AND MINING ENGINEERING

ВЕСТНИК ПНИПУ. ГЕОЛОГИЯ. НЕФТЕГАЗОВОЕ И ГОРНОЕ ДЕ

ISSN 2224-9923

Volume / Tом 16 №4 2017

http://vestnik.pstu.ru/geo

УДК 678.7

Article / Статья

(C) PNRPU / ПНИПУ, 2017

\title{
RELEVANT DIRECTIONS IN DEVELOPMENT OF POLYMER COMPOSITIONS FOR CONDITIONS OF OPERATED IN PERM REGION RESERVOIRS
}

\section{Yuliya A. Ketova}

NefteProm Servis LLC (25 Lizy Chaykinoy st., Perm, 614022, Russian Federation)

\section{АКТУАЛЬНЫЕ НАПРАВЛЕНИЯ РАЗРАБОТКИ ПОЛИМЕРНЫХ СОСТАВОВ В УСЛОВИЯХ ЭКСПЛУАТАЦИОННЫХ ОБЪЕКТОВ ПЕРМСКОГО КРАЯ}

\section{Ю.А. Кетова}

ООО «НефтеПром Сервис» (614022, Россия, г. Пермь, ул. Лизы Чайкиной, 25)

Received / Получена: 12.09.2017. Accepted / Принята: 13.10.2017. Published / Опубликована: 01.12.2017

Key words:

technologies of remedial cementing, crossflows, water inflow, water cut of well production, polymer composition, crosslinked polymer, polyacrylamide, silicates.

\begin{abstract}
According to audit data about $75 \%$ of residual oil reserves of Perm region fields are characterized by water cut of well production of more than $50 \%$. Development of the methods for reducing water inflow is one of the priority areas of research. The paper presents the results of an analysis of available sources for reasons of oil water cut and methods used to eliminate water inflow. A detailed classification of remedial cementing jobs is displayed. The review of chemical methods allowing to block the water inflow in the bottomhole and remote zone of the reservoir is given.

It was established during the analysis that studying of polymeric materials for remedial cementing jobs is a relevant direction. An analysis of domestic and international experience shows that the use of polymeric materials to eliminate water inflows allows to increase oil recovery up to $85-90 \%$. Such parameters as structure (large caverns or cracks of small diameter) and localization of water inflow, temperature, reservoir pressure and formation permeability, characteristics of reservoir fluids dictate individual requirements for the polymer composition in terms of rheology, polymerization kinetics, strength characteristics and thermal stability.

The most urgent task of waterproofing works in the Perm region is the elimination of watered intervals and redistribution of fluid flows into undeveloped less permeable sections of the geological section. In this regard, technology to reduce water inflow with the help of gels with a high penetrating power and high strength after the completion of polymerization are in demand at the deposits of the Perm region. Taking into account the analysis, the technology of polymeric blockage of water inflow using polyacrylamide (PAA) was adopted as the most suitable for conditions of reservoirs of Perm regions. Laboratory tests are carried out to study and select polymer compositions for remedial cementing jobs at the fields of the Perm regions, including the polymerization process depending on the composition $\mathrm{pH}$. The change in viscosity of the polymer composition during the time with a PAA content of $0.75 \%$ and chromium acetate of $0.02 \%$ is studied. As a result of testing the polymer based on PAA, it was found that viscosity of a polymer composition increases with increasing temperature and concentration of the crosslinking agents.
\end{abstract}

По данным аудита, около $75 \%$ остаточных запасов нефти месторождений Пермского края характеризуются обводненностью продукции скважин более 50 \%. Разработка методов снижения водопритока является одним из приоритетных направлений исследований. В статье представлены результаты анализа доступных источников по причинам обводненности нефти и методов, используемых для ликвидации водопритока, отображена подробная классификация ремонтно-изоляционных работ. Приведен обзор химических методов, позволяющих блокировать водоприток в призабойной и удаленной зонах пласта.

В ходе анализа установлено, что изучение полимерных материалов для целей ремонтно-изоляционных работ является приоритетным направлением. Анализ отечественного и международного опыта показывает, что использование полимерных материалов для устранения водопритока позволяет повысить нефтеотдачу до 85-90\%. Такие параметры, как структура (крупные каверны или трещины малого диаметра) и локализация водопритока, температура, пластовое давление и проницаемость пласта, характеристики пластовых флюидов, диктуют индивидуальные требования к полимерной композиции с точки зрения реологии, кинетики полимеризации, прочностных характеристик, термостабильности.

Наиболее актуальной задачей водоизоляционных работ в условиях Пермского края является устранение обводнившихся интервалов и перераспределение фильтрационных потоков в невыработанные менее проницаемые участки геологического разреза. В связи с этим технологии снижения водопритока с помощью гелей с высокой проникающей способностью и высокой прочностью после завершения полимеризации востребованы на месторождениях Пермского края. С учетом проведенного анализа в качестве наиболее подходящей для условий залежей Пермского края принята технология полимерной блокировки водопритока с использованием полиакриламида (ПАА). Проведены лабораторные испытания по изучению и подбору полимерных композиций для ремонтноизоляционных работ на месторождениях Пермского края, в том числе изучен процесс полимеризации в зависимости от $\mathrm{pH}$ раствора. Исследовано изменение вязкости в течение времени полимерного состава с содержанием ПАА $0,75 \%$ и ацетатом хрома $0,02 \%$. В результате испытания полимера на основе ПАА установлено, что вязкость раствора полимера увеличивается при увеличении температуры и концентрации сшивающих агентов.

Yuliya A. Ketova - Engineer Chemist of the Chemistry Analytical Laboratory (mob. tel.: +007 92234201 02, e-mail: ketovaya@npserv.ru)

Кетова Юлия Анатольевна - инженер-химик химико-аналитической лаборатории (моб. тел.: +007 92234201 02, e-mail: ketovaya@npserv.ru). 


\section{Introduction}

Today most of the oil fields in Perm region are on the late stages of development. One of the main features of "old" fields is a high degree of water cut in well production. According to audit data about $75 \%$ of residual oil reserves of Perm region fields are characterized by water cut of well production of more than $50 \%$. That determines the issue of reducing water cuts as one of the key for the efficiency of oil and gas production companies.

Remedial cementing is a standart solution for the issue of high water cut. However, according to [1], during the period of 2011-2014 the average efficiency of remedial cementing according to the data of oil production companies of Perm region was $14-53 \%$, which is lower than other workovers and treatment carried out during the same period. Thus, it is necessary for oil and gas production companies to optimize approaches for remedial cementing (RC), improvement of the known and development of new technological solutions in this direction.

It is known that diagnosis of the causes of water inflow into the well as a whole is determined by a current position of the displacement front, bottomhole and reservoir pressure in the well, reservoir properties (permeability, porosity, thickness), formation fluids properties (density and viscosity), salt concentration in formation water etc. [2]. Analysis of the data mentioned above and qualitative diagnosis are the most important stages of preparation for RC. The article gives a classification of RC in terms of complexity, which reflects the causes of water cut and corresponding technologies to block water inflow. The review of chemical methods allowing to block the water inflow in the bottomhole and remote zones of the reservoir is given.

\section{Classification of technologies for remedial cementing depending on causes of water breakthrough}

There is a classification of RC by their degree of complexity and recommendations on technologies for elimination of causes of water breakthrough into the wells given in [3]. Four categories of RC complexity are identified. The simplest RC include elimination of tubing leaks, blockage of cross-flows, isolation of the water formation from the oil one by a tight impermeable bridge. Conventional technologies used in such cases are cementing, installation of a mechanical patch and less often polymer injection.

The following category of complexity of RC includes measures to eliminate leakage of a column with small-diameter cracks and a network of small capillaries in a casing; blockage of crossflows with adjacent cracks of small diameter and network of channels; cone of water cut in fractures formed as a result of hydraulic fracturing. In order to eliminate these reasons technologies that use polymer gels and reduce water permeability are usually applied; injection of a gel into narrow channels with subsequent cementation of large voids to prevent a gel from washing away is applied often.

The third category of complexity includes such activities as the blocking of cracks and faults that intersect inclined or horizontal wells; blocking of channels connecting the injection and production wells; blocking of the natural system of channels connecting the wells. In such cases gels superabsorbents that increase in volume upon contact with water are used; gel-based suspensions with sand, cellophane or fiber were used as well.

According to [3] the most complicated category of RC includes water coining and flooded intervals of high-permeability reservoirs. In such cases it is necessary to develop an individual technology to eliminate water inflow.

In general, all RC categories can be combined according to the principle of localization of the treatment zone in the well. Three localization zones have been identified in the references that are as follows: a casing string, bottomhole formation zone (BHFZ) and remote formation zone (RFZ) [4, 5]. Casing leaks, as already mentioned, are eliminated mechanically or by cementing. Treatment of BHFZ and RFZ involves the use of cement compositions and polymers, and gels in particular. The difference between these materials is the ability to penetrate narrow cracks, pores and caverns of small diameter. Cement has a low penetrating ability, therefore that is remain on rock surfaces. Such compositions are used mainly for BHFZ. Gels, however, have a higher penetrating power and are suitable for modifying the RFZ profile. Usually, such technologies are used in injection wells $[2,3]$. After the completion of polymerization, a polymeric composition forms an impermeable elastic mass that attaches to the 
surface of the rock, thereby blocking zones of increased permeability.

A detailed study of the mechanism of chemical synthesis of gels allows to adapt a RC technology with use of a polymer to any source of water inflow in both BHFZ and RFZ. This can be achieved by changing the weight of a polymer chain, input of copolymers and crosslinking agents to regulate polymer strength characteristics and its stability at high temperatures; additional additives that affect the polymerization mechanism (for example, polymerization activators) etc. From such the point of view polymeric materials are more versatile because the same polymer under the conditions of well operation can handle a whole complex of tasks related to the reduction of oil water cut. That makes the use of polymers a promising direction for $\mathrm{RC}$ purposes. At the moment, there is a lot of polymers proposed, each of which has its own specific synthesis and initial characteristics. The following chapter provides a brief description of some chemical and technological approaches.

\section{Principles of selecting polymeric materials for remedial cementing}

Polymeric materials used for RC purposes can have very different characteristics that are selected in the course of laboratory tests taking into account characteristics of the well, formation permeability and porosity, causes of water inflow, $\mathrm{pH}$ and ionic strength of formation fluids and other parameters. The main requirements for polymer compositions are optimal viscosity prior to polymerization which allows to deliver polymer to the zone of water inflow localization; chemical stability at reservoir temperature; keeping the shape for a long period (from 6 months to 2 years); optimal polymerization time sufficient for the penetration of a polymer mass into formation pores and capillaries [6].

Today there are several classifications of polymer materials identified (Fig. 1), used for RC purposes. There are single-phase and two-phase (foam and colloidal solutions) compositions defined by the number of phases entering the polymer composition.

Among single-phase gels polymers of organic and inorganic nature are used. Among organic gels, polyacrylamide (PAA) based compositions are widely used [7-11]. Important characteristics of such the polymer are amount of molecular weight and degree of its hydrolysis. They affect thermostability of the polymer. The lower the molecular weight and the higher the degree of hydrolysis the more stable the polymer is at high temperatures [8]. The Fig. 2 shows the hydrolysis of polyacrylamide, which results in the formation of partially hydrolyzed polyacrylamide (PHPAA) [7, 9].

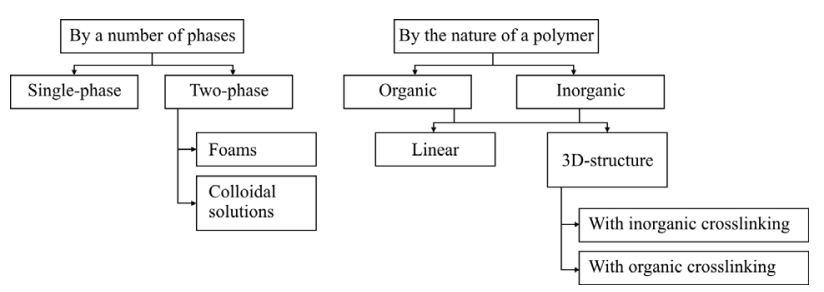

Fig. 1. Classification of polymeric materials

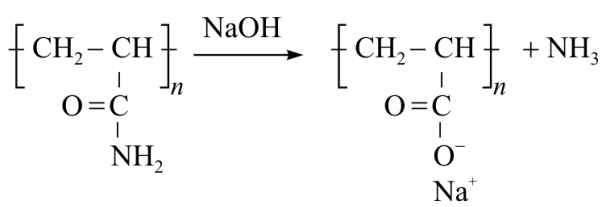

Fig. 2. Scheme of hydrolysis of polyacrylamide

That reaction occurs at high temperatures. In the references it is considered as one of the reasons for the instability of the polycrylamide gel. In order to stabilize the polymer at formation temperatures additional organic monomers, such as phenol, formaldehyde [5, 12], vinylpyrrolidone [11], modifications of acrylamide sulfonates [13] and others are input. A high degree of hydrolysis of the polymer reduces its solubility in the aqueous fraction. A low degree of hydrolysis increases the sensitivity of the polymer to the presence of electrolytes in formation water. In addition to salts, polymer chains are able to interact with surfactants. The mechanism of interaction of sodium oleate and hydrolyzed acrylamide was studied in [14]. An increase in viscosity of the solution was observed at low concentration of surfactants due to hydrogen bonds between polymer chains and sodium oleate. At high concentration of surfactant its molecules repel each other, viscosity decreases due to destruction of bonds between acrylamide and sodium oleate.

In order to form a strong three-dimensional structure of PAA, intermolecular crosslinks, which can be inorganic and organic, are used. The principle of crosslinking is the formation of a covalent bond between the stapler ions and negatively charged carboxyl groups of PAA [4, 15]. There are metal ions among the inorganic 
crosslinks such as $\mathrm{Cr}^{3+}[16,17], \mathrm{Al}^{3+}[18,19]$ etc. Polyethyleneimine [20-22], chitosan, methylenebis-acrylamide etc. can be highlighted among organic crosslinking agents [12].

Another example of an organic polymer is polyurethane, obtained during the polycondensation reaction of an isocyanate with an alcohol at a temperature of $90{ }^{\circ} \mathrm{C}$ (Fig. 3).

$$
\mathrm{R}_{1}-\mathrm{N}=\mathrm{C}=\mathrm{O}+\mathrm{HO}-\mathrm{R}_{2} \longrightarrow \mathrm{R}_{1}-\stackrel{\mathrm{I}}{\mathrm{N}} \stackrel{\stackrel{\mathrm{I}}{\mathrm{C}}}{\mathrm{C}}-\mathrm{R}_{2}
$$

Fig. 3. Scheme for the synthesis of urethane polymers

The approach mentioned requires careful planning of the chemical reaction and selection of substituents due to the fact that the reaction proceeds with release of a large amount of heat. In addition, some substituted isocyanates are explosive and toxic. Laboratory tests of core samples from Berea showed a decrease in permeability from 30.5 to $0.11 \mathrm{mD}$. However, the polymer tends to degrade with time. So, after 3 months permeability of the processed core increased by $19 \%$ [23].

Among the inorganic polymers, silicate-based formulations are widely used. The viscosity of sodium silicate solution, gel time, strength characteristics of the gel depend on such factors as $\mathrm{pH}$, temperature, salt concentration, mechanical shear rate. If the silicate number is greater than 1.6 at low $\mathrm{pH}$, the composition will polymerize. Increased temperature and additional additives activate the polymerization reaction. Thus, the paper [24] describes the technology of using urea hydrolyzed at high temperature as an activator of polymerization.

Two-phase polymer compositions can be used both to eliminate water cut in the BHFZ and to modify the drainage profile in the RFZ. There is in [25] an analysis of a polymer composition consisting of a liquid and gaseous phase based on an ion-crosslinked $\mathrm{Cr}^{3+}$ partially hydrolyzed polyacrylamide in copolymerization with surfactants, which was foamed with nitrogen is given. The advantage of this composition, in the author's opinion, is a low consumption and, accordingly, a low level of costs. The polymer was tested on a sample with a cavern $0.7 \mathrm{~cm}$ when the polymer composition is fed at the rate of $1 \mathrm{~cm}^{3} / \mathrm{min}$, core permeability decreased from 777 to $1.67 \mathrm{D}$.
In connection with the need to regulate the gelling rate, a two-phase system based on liquid and solid phases was developed, represented by nanoparticles of size 100-200 nm. The principle of gelling is based on the crosslinking of partially hydrolyzed PAA with $\mathrm{Cr}^{3+}$ ions, but since the rate of gelling of this system is large (less than $30 \mathrm{~min}$ at $40{ }^{\circ} \mathrm{C}$ ), $\mathrm{Cr}^{3+}$ ions were isolated with polyethyleneimine and sulphodextran. Application of the technology allowed increasing the gel time up to 7 days [26].

Another example of a colloidal system is PAAgels with input of silicate and cement dust with a mass fraction of about $10 \%$, which after polimerization has a solid structure. Such compositions were tested at the well using coiled tubing injection. During the tests, the gel showed a high penetrating ability and a qualitative blockage of the water inflow.

\section{Experience in development of polymer compositions for conditions of operated in Perm region reservoirs}

Thus, at the moment there is a variety of materials and technologies described in papers dedicated for elimination the causes of oil water cut. It is obvious that the methodology of carrying out RC should take into account the reservoir properties of formations of oil deposits. The main production objects in Perm region are confined to both terrigenous (Visean deposits) and carbonate (deposits of the Bashkir and TournaisianFamennian age) reservoirs.

Clastic Visean reservoirs are represented by medium- and fine-grained sandstones, rarely siltstones. The boundary porosity limit, below which there is no fluid flow, for deposits in Visean reservoirs is estimated in the range from 7 to $13 \%$, porosity can reach $24 \%$. Visean deposits in the area of study have a high density and long history of development [27].

Carbonate reservoirs, in comparison with clastic ones, usually have a more heterogeneous composition, which considerably complicates the conditions for their development, including accelerated dynamics of water breakthrough to well production in comparison with deposits in clastic reservoirs [28, 29]. For the carbonate deposits a porous type is caused mainly by secondary intramodern voids. In this case, the type of voidness can be either granular or as a result of leaching of fossil remains of the carbonate composition by a fractured-cavernous one. The 
boundary porosity limit for deposits in carbonate reservoirs is estimated in the range from 5 to $10 \%$, the porosity in the reservoirs rarely exceeds $18 \%$ [30].

Analysis of flow characteristics of deposits in the Perm region shows a high heterogeneity of interlayers by permeability. The process of water breakthrough occurs at the most permeable intervals which can provoke the emergence of water inflows of any complexity category. Diagnosis of the cause of water inflow is the most important preparatory stage for the effective RC application.

The general approach to reducing the water cut in oil production in Perm region is the elimination of intervals with high water cut and redistribution of flows into undeveloped, less permeable sections of a geological section. The technology of reducing water inflow by means of polymeric materials is universal and can be adapted to most of the RC issues. The main requirements for characteristics of polymer composition are as follows: low viscosity of the solution at the injection stage, optimal polymerization time, which depends on the localization of the cause of water cut; stable structure after completion of the polymerization. The most suitable polymers for RC at the Perm region deposits, in the author's view, are polyacrylamide-based compositions. Due to the fact that the average reservoir temperature in Perm region is $25-30{ }^{\circ} \mathrm{C}$, the polymer will be stable at reservoir temperatures. The process of polymerization of acrylamide and dependence of properties of the polymer on additional copolymers and initiators of polymerization are widely covered in scientific papers, which greatly facilitates the process of selecting the composition for RC purposes. For the moment, there are in the research laboratory of NefteProm Servis LLC works conducted to study and select polymer compositions for $\mathrm{RC}$ at Perm region reservoirs. At this time, the polymer of SNF Floergrer FP-207 is accepted for testing. Based on results presented in [16], the process of studying polymerization as a function of the $\mathrm{pH}$ of the solution was initiated. Laboratory tests confirmed the source data [16]: the optimum $\mathrm{pH}$ value for polymerization is in the range from 4.5 to 5.0. The change in viscosity during the time of the polymer composition with a PAA content of $0.75 \%$ and chromium acetate $0.02 \%(\mathrm{pH}=4.91)$ was studied. The change in viscosity of the polymer composition over the time is shown in Fig. 4.

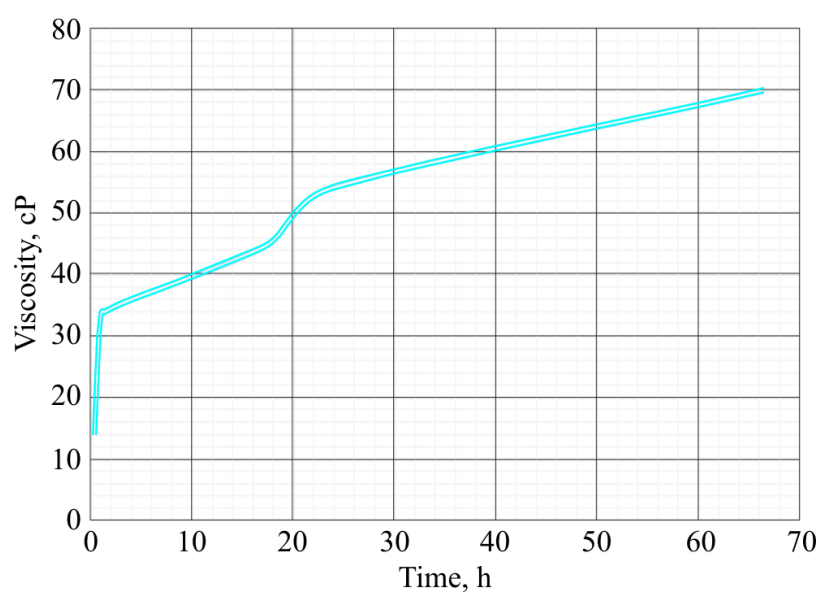

Fig. 4. Change in viscosity of PAA in time

The composition can be recommended for small cracked cavernous zones of water in the RFZ. It is necessary to modify the composition for $\mathrm{RC}$ in BHFZ in order to shorten the polymerization time and increase the strength characteristics of the polymer.

In order to study the polymerization process in the reservoir water of the Perm region deposits, tests were conducted on samples of formation fluids from the reservoir pressure maintenance system at the Pavlovskoe field (table).

Test of polymerization of PAA in formation water

\begin{tabular}{|c|c|c|c|c|c|}
\hline Ratio of tap/formation water, \% & $\begin{array}{c}\text { Mass of water } \\
\text { fraction, } \mathrm{g}\end{array}$ & $\mathrm{pH}$ & Weight PAA, $\mathrm{V}$ & Viscosity, cP & Mixing time by mixer, min \\
\hline $100 / 0$ & 224.86 & 4.16 & 3.378 & 63 & 40 \\
\hline $50 / 50$ & 226.55 & 4.71 & 3.398 & 63 & 40 \\
\hline $0 / 100$ & 222.53 & 4.84 & 3.337 & 68 & 40 \\
\hline
\end{tabular}

It was found during the test that the composition prepared in the formation water has a higher viscosity than the compounds in tap water. The reason for this may be an increased concentration of salts of divalent metals, which acted as crosslinking agents between the chains of PAA. The compositions obtained as a result of the test hardened at a temperature of $93{ }^{\circ} \mathrm{C}$ in 8 hours.

Thus, preliminary tests of a polymer based on PAA showed that the viscosity of a polymer 
solution increases with increasing temperature and concentration of cross-linking agents. A change in viscosity over the time is determined. The results will form the basis for further work on the optimization of the polymer composition and selection of methods for testing the compositions.

\section{References}

1. Iliushin P.Iu., Rakhimzianov R.M., Solov'ev D.Iu., Kolychev I.Iu. Analysis of well intervention aimed at oil production enhancement in the Perm krai's fields. Bulletin of Perm National Research Polytechnic University. Geology. Oil \& Gas Engineering \& Mining, 2015, vol.14, no.15, pp.81-89. DOI: 10.15593/2224-9923/2015.15.9

2. Canbolat S., Parlaktuna M. Well selection criteria for water shut-off polymer gel injection in carbonates. $A b u$ Dhabi International Petroleum Exhibition and Conference, SPE 158059, 2012, pp.1-11. DOI: 10.2118/158059-MS

3. Seright R.S., Lane R.H., Sydansk R.D. A strategy for attacking excess water production. SPE Production and Facilities, 2003, vol.18, no.03, pp.158-169. DOI: 10.2118/84966-PA

4. Akhlaghi Amri H.A. Evaluation of alkaline sodium silicate gel for reservoir in-depth profile modifications to enhance water sweep efficiency in sandstone reservoirs. Ph.D. thesis No. 221. University of Stavanger, 2014, p.115.

5. Eoff L., Dalrymple D., Everett D., Vasquez J. Worldwide field applications of a polymeric gel system for conformance applications. SPE Production \& Operations, 2007, vol.22, no.2, pp.231-236. DOI: 10.2118/98119-PA

6. Lymar I.V. Review of new water shut-off technologies implemented on the oil fields of The Republic Belarus. Oil and Gas Business, 2011, no.5, pp.133-142, available at: http://www.ogbus.ru/eng/ (accessed: 06 September 2017).

7. Simjoo M., Sefti M.V., Koohi A.D., Hasheminasab R., Sajadian V. Polyacrylamide gel polymer as water shut-off system: preparation and investigation of physical and chemical properties in one of the Iranian oil reservoirs conditions. Iranian Journal of Chemistry and Chemical Engineering, 2007, vol.26, no.4, pp.99-108.

8. Sabhapondit A., Borthakur A., Haque I. Characterization of acrylamide polymers for enhanced oil recovery. Journal Applied Polymer Science, 2003, vol.87, no.12, pp.1869-1878. DOI: 10.1002/app.11491

9. Kurenkov V.F., Hartan H.G., Lobanov F.I. Alkaline hydrolysis of polyacrylamide. Russiand Journal of Applied Chemistry, 2001, vol.74, no.4, pp.543-554. DOI: 10.1023/A:1012786826774

10. Sengupta B., Sharma V.P., Udayabhanu G. Gelation studies of an organically cross-linked polyacrylamide water shut-off gel system at different temperatures and $\mathrm{pH}$. Journal of Petroleum Science and Engineering, 2012, vol.81, pp.145-150. DOI: 10.1016/j.petrol.2011.12.016

11. Stahl G.A., Moradi-Araghi A., Doe P.H. High temperature and hardness stable copolymers of vinylpyrrolidone and acrylamide. Water-Soluble Polymers for Petroleum Recovery. Eds. G.A. Stahl, D.N. Schulz. New York, London, Plenum Press, 1988, pp.121-130. DOI: $10.1007 / 978-1-4757-1985-7 \quad 6$
12. Malcolm A. Kelland production chemicals for the oil and gas industry. CRC Press Taylor and Francis Group, 2014, $412 \mathrm{p}$.

13. Wu Y., Wang K.-S., Hu Z., Bai B., Shuler P., Tang Y. A new method for fast screening of long-term thermal stability of water soluble polymers for reservoir conformance control. Society of Petroleum Engineers, 2009, pp.1-11. DOI: 10.2118/124257-MS

14. Borthakur A., Rahman M., Sarmah A., Subrahmanyam B. Partially hydrolyzed polyacrylamide for enhanced oil recovery. Res. Industry, 1995, 40, pp.90-94.

15. El-Karsani K.S.M., Al-Muntasheri G.A., Hussein I.A. Polymer system for water shut off and profile modification: a review over the last decade. SPE Journal, 2014, vol.19, no.01, pp.135-149. DOI: 10.2118/163100-PA

16. Jain R., McCool C.S., Green D.W., Willhite G.P., Michnick M.J. Reaction kinetics of the uptake of chromium (III) acetate by polyacrylamide. SPE Journal, 2005, vol.10, no.03, pp.247-254. DOI: 10.2118/89399-MS

17. Klaveness Th.M., Ruoff P. Kinetics of the cross linking of polyacrylamide with $\mathrm{Cr}$ (III). Analysis of possible mechanisms. The Journal of Physical Chemistry, 1994, vol.98, no.40, pp.10119-10123. DOI: 10.1021/j100091a029

18. Seright R., Peihui H., Dongmei W. Current colloidal dispersion gels are not superior to polymer flooding. P.G.O.D.D., 2006, no.10, pp.71-80. DOI: 1000-3754 (2006) 05-0071-10

19. Seright R. Are colloidal dispersion gels really a viable technology? New Mexico Petroleum Recovery Research Center, available at: http://www.prrc.nmt.edu/ groups/res-sweep/colloidal-gels/ (accessed: 06 September 2017).

20. Adewunmi A.A., Ismail S., Sultan A.S. Study on strength and gelation time of polyacrylamide/ polyethyleneimine composite gels reinforced with coal fly ash for water shut-off treatment. TOC, 2015, vol.132, iss.5. DOI: 10.1002/app.41392

21. Bai Y., Xiong C., Wei F., Li J., Shu Y., Liu D. Gelation study on a hydrophobically associating polymer/polyethylenimine gel system for water shut-off treatment energy fuels, 2015, vol.29, no.2, pp.447-458. DOI: $10.1021 /$ ef502505k

22. Al-Muntasheri G.A., Nasr-El-Din H.A. A study of polyacrylamide-based gels crosslinked with polyethyleneimine. SPE Journal, SPE-105925-PA, 2009, vol.14, no.02. DOI: 10.2118/105925-PA

23. Shafian S.R.M., Hassan A.A.B., Ismail S., Teng L.K., Irawan $\mathrm{S}$. Blocked isocyanate fluid system for water shut off application. IADC/SPE Asia Pacific Drilling Technology Conference and Exhibition. Ho Chi Minh City, Vietnam, 2010. DOI: 10.2118/132813-MS

24. Nasr-El-Din H.A., Taylor K.C. Evaluation of sodium silicate/ urea gels for water shut-off treatments. Journal of Petroleum Science and Engineering, 2005, vol.48, no.3-4, pp.141-160. DOI: 10.1016/j.petrol.2005.06.010 
25. Asghari K., Taabbodi L., Dong M. A new gelfoam system for water shut-off purposes in wormhole reservoirs. SPE International Thermal Operations and Heavy Oil Symposium, Calgary, Alberta, Canada, 2005. DOI: 10.2118/97765-MS

26. Cordova M., Cheng M., Trejo J. Delayed HPAM gelation via transient sequestration of chromium in polyelectrolyte complex nanoparticles. Macromolecules, 2008, vol.41, no.12, pp.4398-4404. DOI: 10.1021/ma80021d

27. Koshkin K.A., Galkin S.V. Oil recovery forecast during reevaluation of visean clastic deposits reserves of north-east Volga-Ural oil and gas province. Bulletin of Perm National Research Polytechnic University. Geology. Oil \& Gas Engineering \& Mining, 2015, vol.14, no.17, pp.16-23. DOI: $10.15593 / 2224-9923 / 2015.17 .2$

28. Iliushin P.Iu., Galkin S.V., Poplaukhina T.B., Luzina N.G. Razrabotka metodiki opredeleniia dinamiki obvodneniia produktsii skvazhin $\mathrm{s}$ uchetom vliianiia geologicheskikh i tekhnologicheskikh pokazatelei [Development of the methodology for well drowning assessment with regard to geological and technological parameters]. Neftianoe khoziaistvo, 2012, no.4, pp.108-110.

29. Galkin S.V., Iliushin P.Iu. Metodika operativnoi otsenki ostatochnykh izvlekaemykh zapasov nefti na osnove analiza dinamiki obvodnennosti produktsii skvazhin [Technique of an operational assessment residual taken stocks of oil on a basis analysis of dynamics of water cutting of production of wells]. Neft', gaz i biznes, 2013, no.7, pp.69-71.

30. Efimov A.A., Savitckii Ia.V., Galkin S.V., Shapiro S. Experience of study of core from carbonate deposits by Xray tomography. Bulletin of Perm National Research Polytechnic University. Geology. Oil \& Gas Engineering \& Mining, 2016, vol.15, no.18, pp.23-32. DOI: $10.15593 / 2224-9923 / 2016.18 .3$

\section{Библиографический список}

1. Илюшин П.Ю., Рахимзянов Р.М., Соловьев Д.Ю., Колычев И.Ю. Анализ проведения геолого-технических мероприятий по увеличению продуктивности добывающих скважин на нефтяных месторождениях Пермского края // Вестник Пермского национального исследовательского политехнического университета. Геология. Нефтегазовое и горное дело. - 2015. - Т. 14, № 15. - C. 81-89. DOI: 10.15593/2224-9923/2015.15.9

2. Canbolat S., Parlaktuna M. Well selection criteria for water shut-off polymer gel injection in carbonates // Abu Dhabi International Petroleum Exhibition and Conference. SPE 158059. - 2012. - P. 1-11. DOI: 10.2118/158059-MS

3. Seright R.S., Lane R.H., Sydansk R.D. A strategy for attacking excess water production // SPE Production and Facilities. - 2003. - Vol. 18, № 03. - P. 158-169. DOI: 10.2118/84966-PA

4. Akhlaghi Amri H.A. Evaluation of alkaline sodium silicate gel for reservoir in-depth profile modifications to enhance water sweep efficiency in sandstone reservoirs. Ph.D. thesis No. 221. - University of Stavanger, 2014. - P.115.

5. Eoff L., Dalrymple D., Everett D., Vasquez J. Worldwide field applications of a polymeric gel system for conformance applications // SPE Production \& Operations. 2007. - Vol. 22, № 2. - P. 231-236. DOI: 10.2118/98119-PA

6. Lymar I.V. Review of new water shut-off technologies implemented on the oil fields of The Republic Belarus [Электронный ресурс] // Oil and Gas Business. - 2011. № 5. - P. 133-142. URL: http://www.ogbus.ru/eng/ (дата обращения: 06.09.2017).

7. Simjoo M., Sefti M.V., Koohi A.D., Hasheminasab R., Sajadian V. Polyacrylamide gel polymer as water shut-off system: preparation and investigation of physical and chemical properties in one of the Iranian oil reservoirs conditions // Iranian Journal of Chemistry and Chemical Engineering. - 2007. - Vol. 26, № 4. - P. 99-108.

8. Sabhapondit A., Borthakur A., Haque I. Characterization of acrylamide polymers for enhanced oil recovery // Journal Applied Polymer Science. - 2003. Vol. 87, № 12. - P. 1869-1878. DOI: 10.1002/app.11491

9. Kurenkov V.F., Hartan H.G., Lobanov F.I. Alkaline hydrolysis of polyacrylamide // Russiand Journal of Applied Chemistry. - 2001. - Vol. 74, № 4. - P. 543-554. DOI: $10.1023 / \mathrm{A}: 1012786826774$

10. Sengupta B., Sharma V.P., Udayabhanu G. Gelation studies of an organically cross-linked polyacrylamide water shut-off gel system at different temperatures and $\mathrm{pH} / /$ Journal of Petroleum Science and Engineering. - 2012. - Vol. 81. - P. 145-150. DOI: 10.1016/j.petrol.2011.12.016.

11. Stahl G.A., Moradi-Araghi A., Doe P.H. High temperature and hardness stable copolymers of vinylpyrrolidone and acrylamide // Water-Soluble Polymers for Petroleum Recovery / Eds. G.A. Stahl, D.N. Schulz. - New York, London: Plenum Press, 1988. P. 121-130. DOI: 10.1007/978-1-4757-1985-7 6

12. Malcolm A. Kelland production chemicals for the oil and gas industry. -2 ed. - CRC Press Taylor and Francis Group, 2014. - P. 412.

13. Wu Y., Wang K.-S., Hu Z., Bai B., Shuler P., Tang Y. A new method for fast screening of long-term thermal stability of water soluble polymers for reservoir conformance control // Society of Petroleum Engineers. 2009. - P. 1-11. DOI: 10.2118/124257-MS

14. Borthaku A., Rahman M., Sarmah A., Subrahmanyam B. Partially hydrolyzed polyacrylamide for enhanced oil recovery // Res. Industry. - 1995. - 40. P. 90-94.

15. El-Karsani K.S.M., Al-Muntasheri G.A., Hussein I.A. Polymer system for water shut off and profile modification: a review over the last decade // SPE Journal. - 2014. - Vol. 19, № 01. - P. 135-149. DOI: 10.2118/163100-PA

16. Jain R., McCool C.S., Green D.W., Willhite G.P., Michnick M.J. Reaction kinetics of the uptake of cromium (III) acetate by polyacrylamide // SPE Journal. - 2005. Vol. 10, № 03. - P. 247-254. DOI: 10.2118/89399-MS 
17. Klaveness Th.M., Ruoff P. Kinetics of the cross linking of polyacrylamide with $\mathrm{Cr}$ (III). Analysis of possible mechanisms // The Journal of Physical Chemistry. - 1994. Vol. 98, № 40. - P. 10119-10123. DOI: 10.1021/j100091a029

18. Seright R., Peihui H., Dongmei W. Current colloidal dispersion gels are not superior to polymer flooding // P.G.O.D.D. - 2006. - № 10. - P. 71-80. DOI: 1000-3754 (2006) 05-0071-10

19. Seright R. Are colloidal dispersion gels really a viable technology? [Электронный ресурс] // New Mexico Petroleum Recovery Research Center. - URL: http://www.prrc.nmt.edu/groups/res-sweep/colloidal-gels/ (дата обращения: 06.09.2017).

20. Adewunmi A.A., Ismail S., Sultan A.S. Study on strength and gelation time of polyacrylamide/ polyethyleneimine composite gels reinforced with coal fly ash for water shut-off treatment // TOC. - 2015. - Vol. 132, iss. 5. DOI: 10.1002/app.41392

21. Bai Y., Xiong C., Wei F., Li J., Shu Y., Liu D. Gelation study on a hydrophobically associating polymer/polyethylenimine gel system for water shut-off treatment energy fuels. - 2015. - Vol. 29, № 2. - P. 447458. DOI: $10.1021 /$ ef502505k

22. Al-Muntasheri G.A., Nasr-El-Din H.A. A study of polyacrylamide-based gels crosslinked with polyethyleneimine // SPE Journal. - 2009. - Vol.14, № 02. - SPE-105925-PA. DOI: 10.2118/105925-PA

23. Shafian S.R.M., Hassan A.A.B., Ismail S., Teng L.K., Irawan S. Blocked isocyanate fluid system for water shut off application // IADC/SPE Asia Pacific Drilling Technology Conference and Exhibition, 1-3 November, Ho Chi Minh City, Vietnam, 2010. - DOI: 10.2118/132813-MS

24. Nasr-El-Din H.A., Taylor K.C. Evaluation of sodium silicate/urea gels for water shut-off treatments // Journal of Petroleum Science and Engineering. - 2005. - Vol. 48, № 3-4. - P. 141-160. DOI: 10.1016/j.petrol.2005.06.010
25. Asghari K., Taabbodi L., Dong M. A New gelfoam system for water shut-off purposes in wormhole reservoirs // SPE International Thermal Operations and Heavy Oil Symposium, 1-3 November, Calgary, Alberta, Canada, 2005. DOI:10.2118/97765-MS

26. Cordova M., Cheng M., Trejo J. Delayed HPAM gelation via transient sequestration of chromium in polyelectrolyte complex Nanoparticles // Macromolecules. 2008. - Vol. 41, № 12. - P. 4398-4404. DOI: $10.1021 / \mathrm{ma} 80021 \mathrm{~d}$

27. Кошкин К.А., Галкин С.В. Возможности прогноза нефтеизвлечения при переоценке запасов визейских терригенных залежей северо-востока Волго-Уральской нефтегазоносной провинции // Вестник Пермского национального исследовательского политехнического университета. Геология. Нефтегазовое и горное дело. - 2015. - Т. 14, № 17. С. 16-23. DOI: $10.15593 / 2224-9923 / 2015.17 .2$

28. Илюшин П.Ю., Галкин С.В., Поплаухина Т.Б., Лузина Н.Г. Разработка методики определения динамики обводнения продукции скважин с учетом влияния геологических и технологических показателей // Нефтяное хозяйство. - 2012. - № 4. C. $108-110$.

29. Галкин С.В., Илюшин П.Ю. Методика оперативной оценки остаточных извлекаемых запасов нефти на основе анализа динамики обводненности продукции скважин // Нефть, газ и бизнес. - 2013. № 7. - С. 69-71.

30. Ефимов А.А., Савицкий Я.В., Галкин С.В., Шапиро С.А. Опыт исследования керна карбонатных отложений методом рентгеновской томографии // Вестник Пермского национального исследовательского политехнического университета. Геология. Нефтегазовое и горное дело. - 2016. - Т. 15, № 18. - С. 23-32. DOI: $10.15593 / 2224-9923 / 2016.18 .3$

Please cite this article in English as:

Ketova Yu.A. Relevant directions in development of polymer compositions for conditions of operated in Perm region reservoirs. Perm Journal of Petroleum and Mining Engineering, 2017, vol.16, no.4, pp.342-349. DOI: 10.15593/2224-9923/2017.4.5

Просьба ссылаться на эту статью в русскоязычных источниках следующим образом:

Кетова Ю.А. Актуальные направления разработки полимерных составов в условиях эксплуатационных объектов Пермского края // Вестник Пермского национального исследовательского политехнического университета. Геология. Нефтегазовое и горное дело. - 2017. - Т.16, №4. - С.342-349. DOI: 10.15593/2224-9923/2017.4.5 